\title{
Impact of Foliar Spray of NPK and Zn on Soybean for Growth, Yield, Quality, Energetics and Carbon Footprint under Dryland Condition at Indore
}

Lalita Bhayal', Aakash¹, M.P. Jain², Divya Bhayal ${ }^{3}$, Kamlesh Meena ${ }^{4}$

10.18805/LR-4748

\begin{abstract}
Background: Dryland is characterised by drought/dry spell (s) of 10 to 15 days and is the main reason for decline in soybean production. The aim of this study was to develop a strategy of drought amelioration by using foliar sprays and enhancement of yield, quality, energetics and carbon footprint.

Methods: A field experiment was carried out at Rajmata Vijayaraje Scindia Krishi Vishwa Vidyalaya, College of Agriculture, Indore, (M.P.) during 2017-18 under spilt-plot design having two main plot treatments viz., foliar application at dry spell $\left(F_{1}\right)$, foliar application after dry spell $\left(F_{2}\right)$ and seven sub plot treatments i.e. different variants of foliar sprays (DVFS). Different growth, yield, quality, energetic and carbon footprint traits were recorded. The data were analyzed using standard statistical procedures.

Result: The highest growth, yield, quality and energetic parameters were recorded for $F_{1}$ as compared to $F_{2}$. In case of DVFS, foliar application of water soluble complex fertilizer 19:19:19 (NPK) @ 0.5\% + 0.5\% ZnSO ${ }_{4}\left(\mathrm{~T}_{4}\right)$ produced maximum values for growth, energetics, carbon footprint, oil $(22.5 \%)$ and protein $(43.1 \%)$ content as well as produced maximum yield.
\end{abstract}

Key words: Carbon footprint, Drought, Energetics, Foliar spray, Zinc sulphate.

\section{INTRODUCTION}

Soybean [Glycine max (L.) Merril] is an important oil seed and protein crop. It is considered the "Golden Bean". Madhya Pradesh is known as the "soybean state" of India, comprising $47.8 \%$ area and $48.4 \%$ of the total national production (DACFW, 2018). It ranks first amongst oilseed crops in the world and contributes nearly 25 per cent of world's total oil production (Basediya et al., 2020).

Drought is a primary constraint to global crop production and global climate change is likely to increase the risk of frequent drought, especially in rain-fed and dryland agriculture. Soybean being a dominant Kharif season crop in India its cultivation corresponds with aberrant weather conditions especially rainfall variability. The aberrant nature of rainfall is often faced in dryland regions and reduces crop productivity because of untimely onset of andlor early withdrawal of monsoon and associated dry spell (s) at any stage in the crop season (Verma and Singh, 2017). Intermediated season i.e. early, mid and terminal droughts are often caused by prolonged dry spell(s) due to breaks in monsoon.

Under drought stress, reduced nutrient availability is one of the most important factors limiting plant growth. Foliar application offers numerous advantages, including satisfying the nutritional need of crop grown in moisture deficient soils in rainfed condition (Pranjit et al., 2015). Foliar fertilisation provides the advantages of low application rates, homogeneous fertilizer dispersion and fast nutritional response. Hiwale (2015) advocated that the significant increment in growth, yield and quality parameters of soybean were observed due to application of $\mathrm{KNO}_{3} @ 1.0 \%$ at 45
${ }^{1}$ Department of Agronomy, Rajmata Vijayaraje Scindia Krishi Vishwa Vidyalaya, College of Agriculture, Indore-452 001, Madhya Pradesh, India.

${ }^{2}$ ICAR-All India Co-ordinated Research Project on Dryland Agriculture, Rajmata Vijayaraje Scindia Krishi Vishwa Vidyalaya, College of Agriculture, Indore-452 001, Madhya Pradesh, India. ${ }^{3}$ Department of Soil Science and Agricultural Chemistry, Rajmata Vijayaraje Scindia Krishi Vishwa Vidyalaya, College of Agriculture, Indore-452 001, Madhya Pradesh, India.

${ }^{4}$ Krishi Vigyan Kendra, ICAR- Indian Institute of Vegetable Research, Malhana, Deoria-274 506, Uttar Pradesh, India.

Corresponding Author: Aakash, Department of Agronomy, Rajmata Vijayaraje Scindia Krishi Vishwa Vidyalaya, College of Agriculture, Indore-452 001, Madhya Pradesh, India.

Email: aakashkushwah7004@gmail.com

How to cite this article: Bhayal, L., Aakash, Jain, M.P., Bhayal, D. and Meena, K. (2022). Impact of Foliar Spray of NPK and Zn on Soybean for Growth, Yield, Quality, Energetics and Carbon Foot Print under Dryland Condition at Indore. Legume Research. DOI: $10.18805 / L R-4748$.

Submitted: 22-07-2021 Accepted: 18-11-2021 Online: 10-01-2022

and 60 DAS. Foliar application of NPK improves the plant's capacity to synthesize, store and transport nutrients. Soybean yield and protein content rise when zinc is applied to the leaves (Kumar et al., 2013). Berglund (2002) noted that foliar application of zinc at vegetative growth stage increased soybean yield. Foliar application of zinc also decreased the adverse effects of drought on seed and 
biological yield of soybean (Kobraee and Shamsi, 2011). Zinc foliar application decreased negative impact of drought and increases quantity and quality of the resulting produce (Mohammad et al., 2015).

Growing energy needs of making chemical fertilizers or other inputs and energy used in various agricultural operations necessitates the development of a production technology that consumes less energy input while producing more energy as output (Aakash et al., 2019). There is a closer relationship between energy, carbon (C) and environment, since any activities/operations in crop system needs energy in terms of inputs i.e. fuel, fertilizers etc. and every input has some carbon emission (direct or indirect) which interact with environment and determined the economic and environmental sustainability of that system (Navaz et al., 2017). Energy, water and carbon are important inputs in the modern agricultural production systems and, therefore, the inter-dependence of these and crop production needs to be evaluated for designing an energy, water and carbon efficient cropping system. The input-output relationship of soybean production systems varies with total biomass productivity, nutrient management and diverse tillage practices. The extreme dependence on fossil fuels (diesel) and other non-renewable energy sources and increasing emission of GHGs have shifted the focus on the judicious use of renewable energy. Thus, there is a need to assess the energy use efficiency and C-footprint of crop production systems.

The hypothesis was that the NPK and $\mathrm{Zn}$ have an important role in water regulation in crops. Their foliar spray may give good response under drought leading to higher crop production, varying energetics patterns and carbon footprint. Thus, the present investigation was aimed to evaluate the growth, yield, rain water use efficiency, energy use patterns and carbon footprint of seven different types of concentrations and combination of NPK and $\mathrm{Zn}$ applied at and after relieving of drought.

\section{MATERIALS AND METHODS}

The experiment was conducted at Rajmata Vijayaraje Scindia Krishi Vishwa Vidyalaya, College of Agriculture, Indore, (M.P.) during 2017-18. Experimental soil was predominantly clayey in texture, slightly alkaline in reaction $(\mathrm{pH} 7.70)$ and low in organic carbon $(0.40 \%)$ and available nitrogen (182 $\left.\mathrm{kg} \mathrm{ha}^{-1}\right)$, medium in available phosphorus $\left(14.10 \mathrm{~kg} \mathrm{ha}^{-1}\right)$ and high in available potash (565 kg ha-1).
During the crop period three dry spell of $11-15$ days i.e. first from 28 June to 12 July 2017, second from 1 to 11 August and third from 24 September to 7 October whereas two events, of high intensity rainfall i.e. more than $50 \mathrm{~mm}$ rains in 24 hours (14 July 2017: $55.6 \mathrm{~mm}$ and 28 august 2017) were recorded. The third dry spell came before harvesting. Table 1 showed dates in which foliar application of fertilizers was done.

The experiment consisted of 14 treatment combinations. It was laid out in a split plot design with 3 replications. The experiment consisted of two main treatments i.e. foliar spray timing (FST) viz., $F_{1}$ : Foliar application at dry spell, $F_{2}$ : Foliar application after dry spell and seven sub treatments i.e. different variants of foliar spray (DVFS) viz., $T_{1}$ : Solution of Urea $1 \% \mathrm{~T}_{2}$ : Solution of Urea $2 \% \mathrm{~T}_{3}$ : Solution of Water soluble complex fertilizer 19:19:19 (NPK) 0.5\% $\mathrm{T}_{4}$ : Solution of Water soluble complex fertilizer 19:19:19 (NPK) 0.5\% $+0.5 \%$ Zinc sulphate $\left(\mathrm{ZnSO}_{4} .7 \mathrm{H}_{2} \mathrm{O}\right), \mathrm{T}_{5}$ : Solution of $0.5 \%$ $\mathrm{ZnSO}_{4} \cdot 7 \mathrm{H}_{2} \mathrm{O}_{6}$ : Water spray and $\mathrm{T}_{7}$-Control.

Chlorophyll content was measured with "Soil and plant analysis development" (SPAD)-502 meter by punching the leaves in the eye of SPAD meter of tagged plants. The photosynthetically active radiation (PAR) intercepted was measured by canopy analyser. By holding the knob like structure direct solar radiation was determined and the transmittance solar radiation was measured by holding the lengthy tube-like structure under the plant canopy inside the experimental plot. Thus, the intercepted PAR was calculated by subtracting the transmittance solar radiation from incident solar radiation.

The energetic was determined by using standard equation (ISA, 2014). The total carbon output of the crop was computed by multiplying crop yield with an average Ccontent of biomass ( $\sim 4 \%$ on a dry weight basis) and the total $\mathrm{C}$-equivalent $\left(\mathrm{C}_{\mathrm{e}}\right) / \mathrm{C}$-input was computed by multiplying the respective input used for raising the crop with their emission coefficient as per West and Marland (2002) and Lal (2004). The C-footprint of dryand soybean production system was done as per Jat et al. (2019). The data were analysed using Statistical Tool for Agricultural Research (STAR) software; while the significance of differences between means values were determined using Tukey's Honest Significant Difference (HSD) at $1 \%$ and $5 \%$ levels.

\section{RESULTS AND DISCUSSION}

\section{Growth parameters}

Maximum plant height $(52.89 \mathrm{~cm})$ was recorded by $F_{1}$ (Table 2)

Table 1: Schedule of foliar application of fertilizer during the experimentation.

\begin{tabular}{|c|c|c|c|c|}
\hline \multicolumn{2}{|c|}{ Dry spell } & \multirow{2}{*}{ Foliar spray } & \multirow{2}{*}{ Date of application } & \multirow{2}{*}{ Crop stage } \\
\hline Occurrence & Duration & & & \\
\hline First & 15 days & $\begin{array}{l}\text { 1. Foliar spray during dry spell } \\
\text { 2. Foliar spray after relieving of dry spell }\end{array}$ & $\begin{array}{l}10 / 07 / 2017 \\
18 / 07 / 2017\end{array}$ & Early vegetative \\
\hline Second & 11 days & $\begin{array}{l}\text { 1. Foliar spray during dry spell } \\
\text { 2. Foliar spray after relieving of dry spell }\end{array}$ & $\begin{array}{l}09 / 08 / 2017 \\
17 / 08 / 2017\end{array}$ & Flowering \\
\hline Third & 14 days & $\begin{array}{l}\text { No spray } \\
\text { No spray }\end{array}$ & $\begin{array}{l}- \\
-\end{array}$ & Before harvesting \\
\hline
\end{tabular}


Impact of Foliar Spray of NPK and Zn on Soybean for Growth, Yield, Quality, Energetics and Carbon Footprint under Dryland....

under FST which was $3.7 \%$ more than that for $F_{2}$. For DVFS the significantly higher plant height $(55.12 \mathrm{~cm})$ was noted in treatment $\mathrm{T}_{2}$-Urea @ 2\%. The increase in plant height in $\mathrm{T}_{2}$ compared to the control was $14.8 \%$. This might be due to the effect of nitrogen, since nitrogen increases cell division and elongation. Mona and Azab (2017) observed that the foliar application of urea increased plant height of soybean. $F_{1}$ posed its significant effect on LAl as compared to $F_{2}$ by producing index value of 3.00 (Table 2). Foliar spray during the dry spells helps in maintenance of turgor pressure of leaves which might be the resulted higher LAI. Shabbir et al. (2015) reported that foliar application of NPK during water stress condition increased water relation and maintained higher turgor. While in DVFS, the significantly higher value of LAI (3.18) was obtained for treatment $T_{4}$ The order of LAI under various foliar spray treatments was $T_{4}>T_{3}>T_{2}>T_{1}>T_{5}>T_{6}>T_{7}$. This result was in line with Ling and Silberbush (2002) who reported that foliar spray of NPK showed tremendous increment in leaf area.

$F_{1}$ accumulated significantly higher dry matter $(20.08 \mathrm{~g}$ plant ${ }^{-1}$ ) over $F_{2}$. This indicates that foliar spraying during dry spells enable plants to do their metabolic function normally, resulting in more dry matter production. Amongst DVFS, the highest dry matter (21.94 g plant ${ }^{-1}$ ) was observed in $\mathrm{T}_{4}$ (Table 2). This finding was supported by Haq and Mallarino (2000) who concluded that the growth parameters were significantly higher for foliar spray of NPK which results in increased total dry matter in soybean. According to Leach and Hameleers (2001) zinc is also crucial in the formation of higher dry matter. The relative growth rate (RGR) was not significantly influenced by FST, while DVFS had exerted its significant effect. Significantly superior RGR (0.0147 $\mathrm{g} \mathrm{g}^{-1}$ day $^{-1}$ ) was attained by $\mathrm{T}_{4}$. The increase in RGR over control was $13.5 \%, 19.7 \%, 23.3 \%, 39.4 \%, 9.0 \%$ and $4.1 \%$ for $\mathrm{T}_{1}$, $\mathrm{T}_{2}, \mathrm{~T}_{3}, \mathrm{~T}_{4}, \mathrm{~T}_{5}$ and $\mathrm{T}_{6}$, respectively. This might be due to adequate supply of macro (NPK) and micro (Zn) nutrients via foliar spray which promotes faster crop growth. Gowthami et al. (2018) observed that application of macro and micronutrient through foliar spray increased relative growth rate as compared to control. The non-significant response of FST to RGR specified that the good rainfall occurred between 60 and 85 DAS has led to sufficient moisture in soil, thus, during these period relative crop growth rate increased at constant rate. Sharma et al. (2019) also reported non-significant response of foliar spray during and after drought stress.

\section{Photosynthetically active radiation and chlorophyll content}

Due to varied LAI, the PAR intercepted also differed significantly. $F_{1}$ and $T_{4}$ intercepted maximum PAR [995.6 and $\left.1002.8\left(\mu \mathrm{mol} \mathrm{m}^{-2} \mathrm{~s}^{-1}\right)\right]$, respectively (Table 3$)$. The PAR intercepted by DVFS stood in the order of $T_{4}>T_{3}>T_{2}>T_{1}>T_{5}>T_{6}>T_{7}$. Significantly more PAR intercepted by $F_{1}$ and $T_{4}$ resulted from taller plant height and more leaf area index. The photosynthetic rate was significantly higher in soybean sprayed with NPK 19:19:19 @ 1.0\% reported by Anjum et al. (2013). In this study, $F_{1}$ recorded significantly higher (37.9) SPAD values than these for $F_{2}$. This specifies that foliar application during dry spells provides nutrients quickly and helps in formation of chlorophyll. $\mathrm{T}_{4}$ had significant more SPAD values 40.5 as compared to control. Amanmmula et al. (2014) observed that water soluble NPK fertilizer significantly increased the PAR interception and

Table 2: Effect of different foliar sprays and their timings on the growth attributes of soybean.

\begin{tabular}{|c|c|c|c|c|}
\hline Treatments & $\begin{array}{l}\text { Plant height } \\
(\mathrm{cm})\end{array}$ & $\begin{array}{l}\text { Leaf area } \\
\text { index }\end{array}$ & $\begin{array}{l}\text { Dry matter } \\
\left(\text { g plant }^{-1}\right)\end{array}$ & $\begin{array}{r}\text { RGR }\left(\mathrm{g} \mathrm{g}^{-1} \text { day }^{-1}\right) \\
\text { between } 60-80 \text { DAS }\end{array}$ \\
\hline \multicolumn{5}{|l|}{ Foliar spray timing (FST) } \\
\hline $\mathrm{F}_{1}: \mathrm{FS}$ at dry spell & $52.89^{a}$ & $3.00^{\mathrm{a}}$ & $20.08^{a}$ & $0.0125^{a}$ \\
\hline$F_{2}: F S$ after dry spell & $51.00^{\mathrm{b}}$ & $2.65^{\mathrm{b}}$ & $18.72^{\mathrm{b}}$ & $0.0120^{a}$ \\
\hline $\operatorname{HSD}(P \leq 0.05)$ & 1.88 & 0.31 & 1.26 & NS \\
\hline \multicolumn{5}{|l|}{ Different variants for foliar sprays (DVFS) } \\
\hline $\mathrm{T}_{1}:$ Urea @1\% & $51.75^{\text {bc }}$ & $2.71^{\mathrm{a}}$ & $19.57^{\mathrm{bc}}$ & $0.0119^{a b c}$ \\
\hline $\mathrm{T}_{2}:$ Urea @2\% & $55.12^{\mathrm{a}}$ & $3.06^{\mathrm{a}}$ & $19.61^{\mathrm{b}}$ & $0.0126^{a b c}$ \\
\hline $\mathrm{T}_{3}:$ 19:19:19 (NPK) @0.5\% & $52.58^{\mathrm{abc}}$ & $3.09^{a}$ & $20.1^{\mathrm{ab}}$ & $0.0135^{\mathrm{ab}}$ \\
\hline $\mathrm{T}_{4}: 19: 19: 19(\mathrm{NPK}) @ 0.5 \%+\mathrm{ZnSO}_{4} @ 5 \%$ & $54.93^{\mathrm{ab}}$ & $3.18^{a}$ & $21.94^{\mathrm{a}}$ & $0.0147^{a}$ \\
\hline $\mathrm{T}_{5}: \mathrm{ZnSO}_{4} @ 5 \%$ & $51.73^{\mathrm{bc}}$ & $2.68^{a}$ & $19.02^{\mathrm{bc}}$ & $0.0115^{\mathrm{bc}}$ \\
\hline $\mathrm{T}_{6}:$ Water spray & $49.53^{\text {cd }}$ & $2.54^{\mathrm{a}}$ & $18.41^{\mathrm{bc}}$ & $0.0109^{b c}$ \\
\hline $\mathrm{T}_{7}:$ Control & $47.98^{d}$ & $2.51^{\mathrm{a}}$ & $17.67^{c}$ & $0.0105^{c}$ \\
\hline HSD $(P \leq 0.05)$ & 3.20 & 0.48 & 1.18 & 0.0018 \\
\hline \multicolumn{5}{|l|}{ Source of variance } \\
\hline F S timing & * & * & * & NS \\
\hline DVFF & ** & NS & * & $* *$ \\
\hline FST $\times$ DVFF & NS & NS & NS & NS \\
\hline
\end{tabular}

HSD $=$ Tukeys's honest significant difference; Significance levels: ${ }^{*} \mathrm{P} \leq 0.05 ;{ }^{*} \mathrm{P} \leq 0.01 ; \mathrm{NS}=$ Non significant; FS= Foliar spray. Differences between means with the same letter are not significant. 
Impact of Foliar Spray of NPK and Zn on Soybean for Growth, Yield, Quality, Energetics and Carbon Footprint under Dryland....

Table 3: Effect of different foliar sprays and their application timings on PAR, chlorophyll content, seed yield and quality parameters of soybean.

\begin{tabular}{|c|c|c|c|c|}
\hline Treatments & 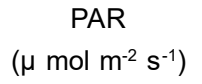 & $\begin{array}{c}\text { Chlorophyll } \\
\text { content (SPAD) }\end{array}$ & $\begin{array}{l}\text { Oil content } \\
(\%)\end{array}$ & $\begin{array}{c}\text { Protein } \\
\text { content(\%) }\end{array}$ \\
\hline \multicolumn{5}{|l|}{ Foliar spray timings (FST) } \\
\hline $\mathrm{F}_{1}: \mathrm{FS}$ at dry spell & $995.6^{\mathrm{a}}$ & $37.9^{a}$ & $22.3^{a}$ & $42.6^{a}$ \\
\hline $\mathrm{F}_{2}: \mathrm{FS}$ after dry spell & $980.9^{b}$ & $35.7^{\mathrm{b}}$ & $22.1^{\mathrm{b}}$ & $41.9^{\mathrm{b}}$ \\
\hline $\mathrm{HSD}(P \leq 0.05)$ & 13.2 & 1.2 & 0.03 & 0.10 \\
\hline \multicolumn{5}{|l|}{ Different variants of foliar sprays (DVFS) } \\
\hline $\mathrm{T}_{1}:$ Urea @1\% & $978.3^{\mathrm{bc}}$ & $36.5^{\mathrm{ab}}$ & $22.2^{\mathrm{b}}$ & $42.5^{\mathrm{ab}}$ \\
\hline $\mathrm{T}_{2}:$ Urea @2\% & $986.4^{\mathrm{ab}}$ & $37.2^{\mathrm{ab}}$ & $22.3^{\mathrm{ab}}$ & $42.8^{\mathrm{ab}}$ \\
\hline $\mathrm{T}_{3}: 19: 19: 19$ (NPK) @0.5\% & $991.3^{\mathrm{ab}}$ & $39.2^{\mathrm{ab}}$ & $22.4^{\mathrm{ab}}$ & $42.9^{\mathrm{ab}}$ \\
\hline $\mathrm{T}_{4}: 19: 19: 19$ (NPK) @0.5\% + ZnSO $@$ @5\% & $1002.8^{\mathrm{a}}$ & $40.5^{\mathrm{a}}$ & $22.5^{\mathrm{a}}$ & $43.1^{\mathrm{a}}$ \\
\hline $\mathrm{T}_{5}: \mathrm{ZnSO}_{4} @ 5 \%$ & $975.1^{\mathrm{bc}}$ & $35.5^{\mathrm{ab}}$ & $22.1^{\mathrm{bc}}$ & $42.3^{\mathrm{ab}}$ \\
\hline $\mathrm{T}_{6}:$ Water spray & $955.4^{c}$ & $34.5^{\mathrm{ab}}$ & $21.9^{\mathrm{bc}}$ & $41.6^{\mathrm{bc}}$ \\
\hline $\mathrm{T}_{7}:$ Control & $943.4^{c}$ & $34.0^{\mathrm{b}}$ & $21.8^{c}$ & $40.7^{c}$ \\
\hline HSD $(P \leq 0.05)$ & 18.3 & 6.4 & 0.2 & 1.4 \\
\hline \multicolumn{5}{|l|}{ Source of variance } \\
\hline F S timing & * & * & * & NS \\
\hline DVFF & * & * & * & * \\
\hline FST $\times$ DVFF & NS & NS & NS & NS \\
\hline
\end{tabular}

$\mathrm{HSD}=$ Tukeys's honest significant difference; Significance levels: ${ }^{*} \mathrm{P} \leq 0.05 ;{ }^{*} \mathrm{P} \leq 0.01 ; \mathrm{NS}=$ Non significant; FS $=$ Foliar spray. Differences between means with the same letter are not significant.

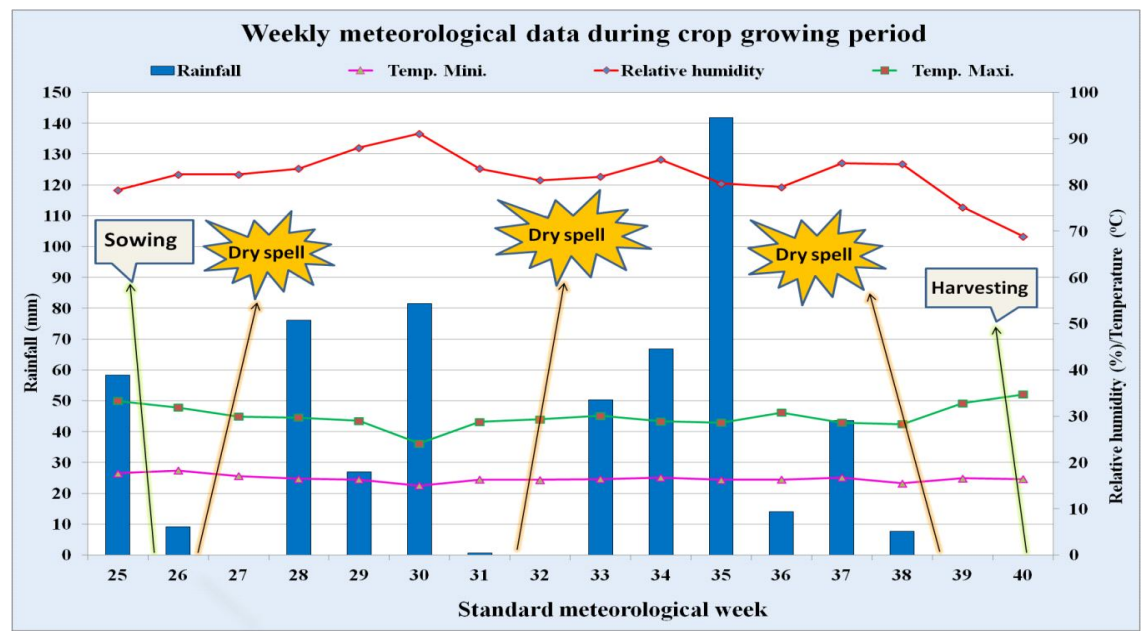

Fig 1: Weekly meteorological data during crop growing period.

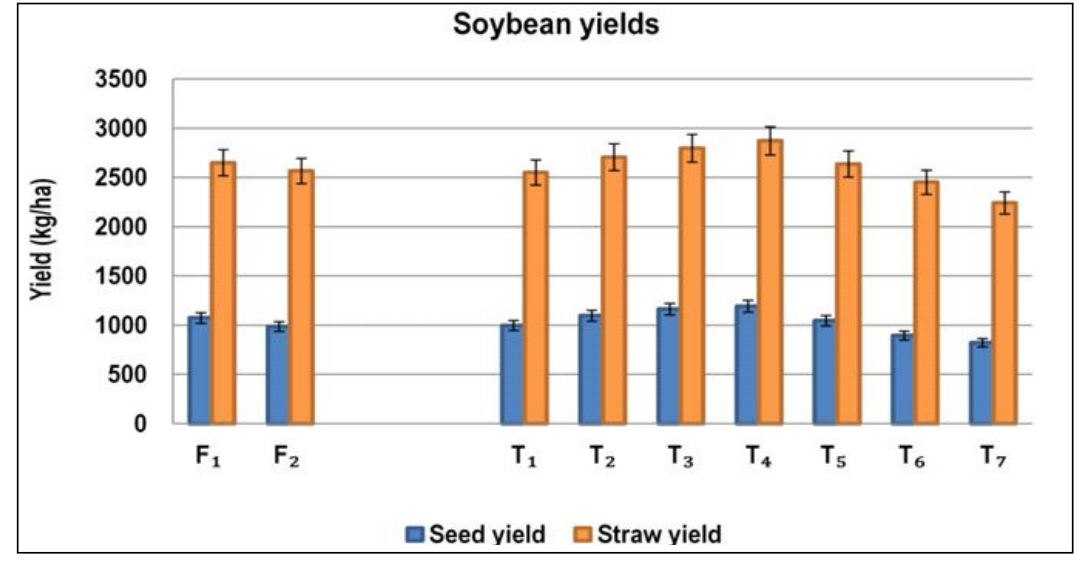

Fig 2: Effect of foliar spray and its timing on seed and straw yield of soybean. 


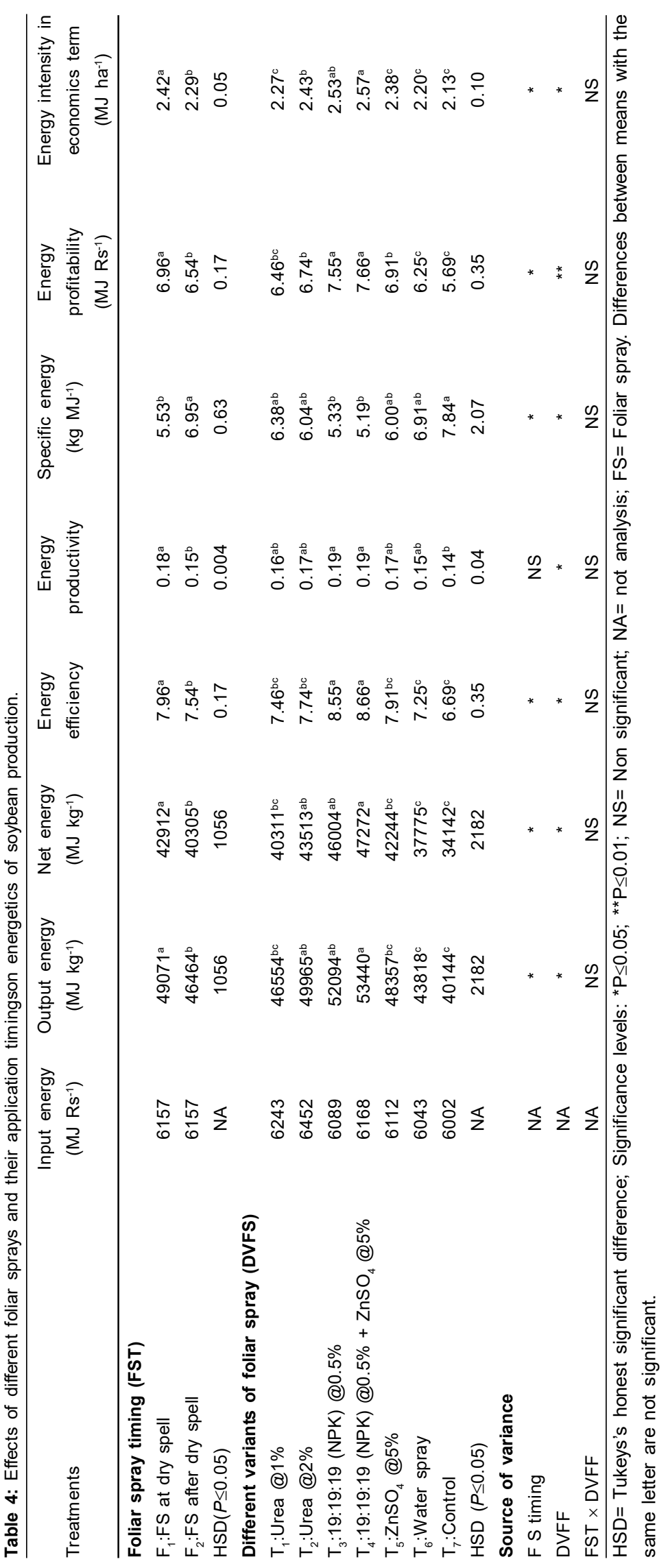


Impact of Foliar Spray of NPK and Zn on Soybean for Growth, Yield, Quality, Energetics and Carbon Footprint under Dryland....

net photosynthetic rate because of higher chlorophyll production and leaf area.

\section{Seed yield}

Different foliar spray treatments produced varying response on plant height, LAI, dry matter accumulation that may have brought differences in seed yield. $F_{1}$ produced maximum seed yield $\left(1075 \mathrm{~kg} \mathrm{ha}^{-1}\right)$ compared to that for $\mathrm{F}_{2}$. The highest seed yield was reported by $\mathrm{T}_{4}\left(1193 \mathrm{~kg} \mathrm{ha}^{-1}\right)$ (Fig 2) which was statistically superior to $T_{1}, T_{6}$ and $T_{7}$ and was similar to the other remaining treatments. $T_{4}$ produced $45 \%$ more seed yield compared to the control. $\mathrm{F}_{1}$ and $\mathrm{T}_{4}$ also had maximum straw yields of 2650 and $2872 \mathrm{~kg} \mathrm{ha}^{-1}$. Malik et al. (2015) observed that significant increase in yield was because of

Table 5: Effects of different foliar sprays and their application timings on carbon footprint of soybean production.

\begin{tabular}{|c|c|c|c|c|c|}
\hline Treatments & $\begin{array}{c}\text { Carbon } \\
\text { input } \\
\left(\mathrm{kg} \mathrm{C}_{\mathrm{e}} \mathrm{ha}^{-1}\right) \\
\end{array}$ & $\begin{array}{c}\text { Carbon } \\
\text { output } \\
\left(\mathrm{kg} \mathrm{C}_{\mathrm{e}} \mathrm{ha}^{-1}\right) \\
\end{array}$ & $\begin{array}{l}\text { Carbon } \\
\text { efficiency }\end{array}$ & $\begin{array}{c}\text { Carbon } \\
\text { sustainability } \\
\text { index }\end{array}$ & $\begin{array}{c}\text { Carbon } \\
\text { efficiency } \\
\text { ratio }\end{array}$ \\
\hline \multicolumn{6}{|l|}{ Foliar spray timing (FST) } \\
\hline $\mathrm{F}_{1}: \mathrm{FS}$ at dry spell & 150.7 & $1639.2^{\mathrm{a}}$ & $10.87^{a}$ & $9.87^{a}$ & $3.32^{\mathrm{a}}$ \\
\hline $\mathrm{F}_{2}:$ FS after dry spell & 150.7 & $1563.8^{a}$ & $10.37^{a}$ & $9.37^{a}$ & $2.70^{\mathrm{a}}$ \\
\hline HSD $(P \leq 0.05)$ & NA & NS & NS & NS & NS \\
\hline \multicolumn{6}{|l|}{ Different variants of foliar spray (DVFS) } \\
\hline $\mathrm{T}_{1}:$ Urea @1\% & 148.5 & $1561.5^{\mathrm{abc}}$ & $10.51^{\mathrm{ab}}$ & $9.51^{\mathrm{ab}}$ & $2.96^{\mathrm{bc}}$ \\
\hline $\mathrm{T}_{2}:$ Urea @2\% & 153.0 & $1673.8^{a b}$ & $10.94^{\mathrm{ab}}$ & $9.94^{\mathrm{ab}}$ & $3.16^{\mathrm{ab}}$ \\
\hline $\mathrm{T}_{3}: 19: 19: 19$ (NPK) @0.5\% & 145.2 & $1743.5^{\mathrm{ab}}$ & $12.01^{\mathrm{a}}$ & $11.01^{\mathrm{a}}$ & $3.53^{\mathrm{ab}}$ \\
\hline $\mathrm{T}_{4}: 19: 19: 19$ (NPK) @0.5\% + ZnSO 4 @5\% & 160.9 & $1788.4^{\mathrm{a}}$ & $11.12^{\mathrm{ab}}$ & $10.12^{\mathrm{ab}}$ & $3.27^{a}$ \\
\hline $\mathrm{T}_{5}: \mathrm{ZnSO}_{4} @ 5 \%$ & 159.7 & $1621.1^{a b c}$ & $10.15^{\mathrm{ab}}$ & $9.15^{\mathrm{ab}}$ & $2.88^{\mathrm{bc}}$ \\
\hline $\mathrm{T}_{6}:$ Water spray & 144.0 & $1473.1^{\mathrm{bc}}$ & $10.23^{\mathrm{ab}}$ & $9.23^{a b}$ & $2.73^{b c}$ \\
\hline $\mathrm{T}_{7}:$ Control & 143.6 & $1349.1^{c}$ & $9.40^{\mathrm{b}}$ & $8.40^{\mathrm{b}}$ & $2.53^{c}$ \\
\hline $\operatorname{HSD}(P \leq 0.05)$ & NA & 201.2 & 1.31 & 1.29 & 0.52 \\
\hline \multicolumn{6}{|l|}{ Source of variance } \\
\hline F S timing & NA & NS & NS & NS & NS \\
\hline DVFF & NA & ** & * & * & * \\
\hline $\mathrm{FST} \times \mathrm{DVFF}$ & NA & NS & NS & NS & * \\
\hline
\end{tabular}

$\mathrm{HSD}=$ Tukeys's honest significant difference; Significance levels: ${ }^{*} \mathrm{P} \leq 0.05 ;{ }^{* *} \mathrm{P} \leq 0.01 ; \mathrm{NS}=$ Non significant; NA= not analysis; $F S=$ foliar spray. Differences between means with the same letter are not significant.

Table 6: Effects of different foliar spray and their application timings on economics of soybean.

\begin{tabular}{|c|c|c|c|c|}
\hline Treatments & $\begin{array}{l}\text { Cost of cultivation } \\
\left(\text { Rs ha }^{-1}\right)\end{array}$ & $\begin{array}{l}\text { Gross returns } \\
\quad\left(\mathrm{Rs} \mathrm{ha}^{-1}\right)\end{array}$ & $\begin{array}{l}\text { Net returns } \\
\left(R^{2} \mathrm{ha}^{-1}\right)\end{array}$ & $\mathrm{B}: \mathrm{C}$ \\
\hline \multicolumn{5}{|l|}{ Foliar spray timing (FST) } \\
\hline $\mathrm{F}_{1}: \mathrm{FS}$ at dry spell & 20218 & $32253^{\mathrm{a}}$ & $12034^{a}$ & 1.60 \\
\hline $\mathrm{F}_{2}: \mathrm{FS}$ after dry spell & 20218 & $29600^{\mathrm{a}}$ & $9381^{a}$ & 1.46 \\
\hline HSD $(P \leq 0.05)$ & NA & NS & NS & NA \\
\hline \multicolumn{5}{|c|}{ Different variants of foliar spray (DVFS) } \\
\hline $\mathrm{T}_{1}:$ Urea @1\% & 20494 & $29900^{\mathrm{abc}}$ & $9406^{\mathrm{abc}}$ & 1.46 \\
\hline $\mathrm{T}_{2}:$ Urea @2\% & 20539 & $32915^{\mathrm{ab}}$ & $12376^{\mathrm{abc}}$ & 1.60 \\
\hline $\mathrm{T}_{3}: 19: 19: 19$ (NPK) @0.5\% & 20625 & $34946^{a}$ & $14321^{\mathrm{ab}}$ & 1.69 \\
\hline $\mathrm{T}_{4}: 19: 19: 19 @ 0.5 \%$ + ZnSO $4 @ 5 \%$ & 20782 & $35790^{\mathrm{a}}$ & $15008^{a}$ & 1.72 \\
\hline $\mathrm{T}_{5}: \mathrm{ZnSO}_{4} @ 5 \%$ & 20306 & $31398^{a b c}$ & $11092^{\mathrm{abc}}$ & 1.55 \\
\hline $\mathrm{T}_{6}:$ Water spray & 19921 & $26852^{\mathrm{bc}}$ & $6931^{\mathrm{bc}}$ & 1.35 \\
\hline $\mathrm{T}_{7}:$ Control & 18865 & $24685^{c}$ & $5820^{c}$ & 1.31 \\
\hline $\mathrm{HSD}(P \leq 0.05)$ & NA & 7741.73 & 7680.5 & NA \\
\hline \multicolumn{5}{|l|}{ Source of variance } \\
\hline F S timing & NA & NS & NS & NA \\
\hline DVFF & NA & $\star *$ & $* *$ & NA \\
\hline $\mathrm{FST} \times \mathrm{DVFF}$ & NA & NS & NS & NA \\
\hline
\end{tabular}

$\mathrm{HSD}=$ Tukeys's honest significant difference; Significance levels: ${ }^{*} \mathrm{P} \leq 0.05 ;{ }^{* *} \mathrm{P} \leq 0.01 ; \mathrm{NS}=$ Non significant; $\mathrm{NA}=$ not analysis; $\mathrm{FS}=\mathrm{Foliar}$ spray. Differences between means with the same letter are not significant. 
application of zinc + urea compared to the control. Mannan (2014) also stated that highest values for seed and straw yields were recorded for the NPK and Mg sprays during drought. Choudhary et al. (2014) discovered that foliar $\mathrm{Zn}$ spraying increased seed yield.

\section{Protein and oil content}

Variation in seed yield under different treatments also produced significant differences in oil and protein content (Table 3). $F_{1}$ recorded significantly higher oil and protein content than these for $F_{2} . T_{4}$ yielded significantly more oil as compared to $T_{6}$ and $T_{7}$. Maximum protein content noticed by $T_{4}(43.1 \%)$ and minimum by $T_{7}$. Increase in protein content might be due to zinc which is important structural element of protein synthesizing enzymes (Ravi et al., 2008). Zambre et al. (2017) found that foliar spray of zinc enhances the level of soluble protein and oil content under water limited conditions and also mitigated adverse effect of dry spell.

\section{Energetics}

Maximum energy input was observed in $\mathrm{T}_{2}$ (6452 $\mathrm{MJ}^{-1}$ ha because nitrogen production has huge energy requirements, while $T_{7}$ (control) recorded the lowest energy input consumption (Table 4) since it does not use any special treatment/input material. All the energetic parameters were significantly influenced by FST and DVFS. The highest output energy was received from $\mathrm{T}_{4}\left(53440 \mathrm{MJ} \mathrm{ha}^{-1}\right)$ measure as seed yield. Similarly, maximum net energy was also recorded by $\mathrm{T}_{4}$ (47272 $\mathrm{MJ} \mathrm{ha}^{-1}$ ) because it has less input demand and more output energy. Likewise, the energy efficiency, energy productivity and energy intensity in economic terms were significantly higher in $\mathrm{T}_{4}$, however, the specific energy was significantly higher in $T_{7}$ (7.84 MJ $\left.\mathrm{kg}^{-1}\right)$. Energetics findings of this study are similar to those of Navaz et al. (2017).

\section{Carbon footprint}

Carbon is a main integral part of the agriculture production system. C-budgeting of FST did not differ significantly (Table 5). The maximum and minimum $\mathrm{C}$-inputs were consumed by $\mathrm{T}_{4}\left(160.9 \mathrm{~kg} \mathrm{C}_{\mathrm{e}} \mathrm{ha}^{-1}\right)$ and $\mathrm{T}_{7}\left(140.6 \mathrm{~kg} \mathrm{C}_{\mathrm{e}} \mathrm{ha}^{-1}\right)$. The chemical fertilizers accounted for more amount of $\mathrm{C}$-share (Jat et al., 2019). It might the reason that $T_{4}$ and $T_{7}$ have maximum and minimum $\mathrm{C}$-input consumption. Maximum C-output was produced by treatment $\mathrm{T}_{4}\left(1788.4 \mathrm{~kg} \mathrm{C}_{\mathrm{e}} \mathrm{ha}^{-1}\right)$. The trend followed for C-output was $\mathrm{T}_{4}>\mathrm{T}_{3}>\mathrm{T}_{2}>\mathrm{T}_{5}>\mathrm{T}_{1}>\mathrm{T}_{6}>\mathrm{T}_{7}$. Kumar et al. (2020) observed that more biomass production was the prime reason for maximum C-output. We also observed similar results in the present study. $T_{3}$ had the highest $C$ efficiency (12.01) followed by $T_{4}$. The sustainability of agricultural production systems mainly depends on their Cfootprints. The C-footprints of soybean production system is highly dependent on ability of the crop to convert the nutrients into grains. The treatment $\mathrm{T}_{3}$ recorded high carbon sustainability index value (CSI) (11.01) whereas the lowest CSI was observed in $T_{7}$. Similarly, $T_{3}$ had more carbon efficiency ratio (CER) compared to other treatments. This might be due to good yield and low C-input consumption under $T_{3}$. These results from the present experimentation are in close agreement to those reported by Rakesh (2020).

\section{Economics}

FST were recorded equal cost i.e. Rs 20218 ha $^{-1}$ while in DVFF; the maximum cost (Rs $20782 \mathrm{ha}^{-1}$ ) was recorded by $\mathrm{T}_{4}$ followed by $\mathrm{T}_{3}$ (Rs $20625 \mathrm{ha}^{-1}$ ). $\mathrm{T}_{4}$ achieved maximum gross income (Rs $35790 \mathrm{ha}^{-1}$ ) and net income (Rs 15008 ha $^{-1}$ ) (Table 6). Singh et al. (2018) reported that foliar application of water soluble fertilizer 19:19:19 (NPK) @ 2\% in soybean gain maximum net returns. Table 6 again confirmed that $F_{1}$ and $T_{4}$ fetched highest values of $B-C$ ratio i.e. 1.60 and 1.72 respectively.

\section{CONCLUSION}

This study showed that foliar spray of water-soluble complex fertilizer 19:19:19 (NPK) @0.5\% + 0.5\% ZnSO at dry spell is a good drought mitigation technology to promote crop growth sufficiently enough. It proved sound for growth, yield, quality, energy and carbon footprint beneficial to dryland farmers.

\section{REFERENCES}

Aakash, Lalita, B., Thakur, N.S., Kirar, S.K. and Choudhary, S.K. (2019). Energetics of maize production system as influenced by varieties and nitrogen scheduling. J. Experimental Bio. Agricultural Sci. 7(5): 462-467. DOI: 10.18006/2019.7(5).462.467 Amanmmula, D., Sinha, K.K. and Sharma, R.P. (2014). Effect of organic manure, NPK and boron application on the productivity of wheat in sandy loam soil of north Bihar. Indian J. Pulses Res. 17: 42-44.

Anjum, S.A., Ehsanullah, L., Wang, L., Saleem, M.F. and Huang, C. (2013). Exogenous benzoic acid (BZA) treatment can induce drought tolerance in soybean plants by improving gas-exchange and chlorophyll contents. Australian J. Crop Sci. 20: 555-560.

Basediya, P., Kumar, P., Gupta, R., Bhargava, M.K., Singh, P. and Kushwaha, N.K. (2020). Study the effect of ridge and furrow system on soybean cultivation in Shivpuri district of M.P. Int. Arch. App. Sci. Technol. 11: 111-115.

Berglund, D.R. (2002). Soybean production field guide for North Dakota and Northwestern Minnesota. Published in cooperative and with support from the North Dakota. Soybean Council. 136-138.

Choudhary, P., Jhajharia, A. and Kumar, R. (2014). Influence of sulphur and zinc fertilization on yield, yield components and quality traits of soybean (Glycine max L.). The Bioscan. 9: $137-142$

DACFW (2018). Agricultural Statistics at a Glance 2018, Government of India Ministry of Agriculture and Farmers Welfare, Department of Agriculture, Cooperation and Farmers Welfare. 115.

Gowthami, P., Rao, G.R., Rao, K.L.N. and Ahamed, L.M. (2018). Effect of foliar application of potassium, boron and zinc on quality and seed yield in soybean.Int. J. Chem. Stud. 6: $142-144$. 
Impact of Foliar Spray of NPK and Zn on Soybean for Growth, Yield, Quality, Energetics and Carbon Footprint under Dryland....

Haq, M.U. and Mallarino, A.P. (2000). Soybean yield and nutrient composition as affected by early season foliar fertilization. J. Agron. 92: 16-24.

Hiwale, R. (2015). Effect of foliar application of potassium nitrate on yield, growth and quality of soybean [Glycine $\max (\mathrm{L}$. Merrill]. Int. J. Agric. Sci. 7: 516-519.

ISA (2014). Agronomy Terminology, $6^{\text {th }}$ Edition, Indian Society of Agronomy, New Delhi.

Jat, S.L, Parihar, C.M., Singh, A.K., Kumar, B., Choudhary M. and Nayak H.S. (2019).Energy auditing and carbon footprint under long-term conservation agriculture based intensive maize systems with diverse inorganic nitrogen management options. Sci. Total Environ. 664: 659-668.

Kobraee, S. and Shamsi, K. (2011). Effects of Zn, Fe and Mn on soybean production. Ecol. 17: 23-28.

Kumar, R., Mishra, J.S., Rao, K.K., Mondal, S., Hazra, K.K. and Choudhary J.S. (2020). Crop rotation and tillage management options for sustainable intensification of rice-fallow agro-ecosystem in eastern India. Sci. Rep. 10: 1-15.

Kumar, V., Vaiyapuri, K., Amanullah, M.M. and Gopalswamy, G. (2013). Infiuence of foliar spray of nutrients on yield and economics of soybean. J. Bio. Sci. 13: 563-65.

Lal, R. (2004). Carbon emission from farm operations. Environ. Int. 30: 981-990.

Leach, K. and Hameleers A. (2001). The effects of a foliar spray containing phosphorus and zinc on the development, composition and yield of forage maize. Grass and Forage Sci. 56: 311-315.

Malik, K., Kumar, S. and Sing, K.P. (2015). Effect of zinc, molybdenum and urea on growth and yield of mungbean (Vigna radiate L. Wilczek). Adv. Res. J. Crop Improv. 6: 59-65.

Mannan, M.A. (2014). Foliar and soil fertilization effect on seed yield and protein content of soybean. Bangladesh Agron. J. 17: 67-72.

Mohammad, Z.L., Khan, I., Rashid, W.K., Asraf, S.A. and Sajid, M. (2015). Foliar application of micronutrient enhances wheat growth, yield and yield related Attributes. American J. of Plant Sci. 5: 864 -869.

Mona, E. and Azab, E.I. (2017). Soybean yield and quality as affected by spraying NPK fertilizers compound with amino acids and micronutrients. Int. J. Chem. Technol. 10: 534543.
Navaz, M., Kumar, Chandrakar, Dameshwar and Ahmad, A. (2017). Impact of foliar spray of nutrients and seed treatment on economics and energetics of lathyrus (Lathyrus sativus L.) under relay cropping system. J. Pharmacognosy and Phytochemistry, 6: 1683-1686.

Pranjit, P.K., Hazarika, M., Sarma, D., Saikia, P., Pankaj Kumar, N., Rajbongshi, R., Nikhita, K., Bhattacharjee, M. and Srinivasarao, Ch. (2015). Effect of foliar application of potassium on yield, drought tolerance and rain water use efficiency of toria under rainfed upland situation of Assam. Indian J. of Dryland Agriculture Res. Develop. 30: 55-59.

Rakesh, K., Mishra, J.S., Mondal, S., Meena, R.S., Sundaram, P.K., Bhatt, B.P., Pan, R.S., Lal, R., Saurabh, K., Chandra, N., Samal, S.K., Hans, H. and Raman, R.K. (2020). Designing an ecofriendly and carbon-cum-energy efficient production system for the diverse agroecosystem of South Asia Energy. Energy. 214.

Ravi, S., Channal, H.T., Hebsur, N.S., Patil, B.N. and Dharmatti P.R. (2008). Effect of sulphur, zinc and iron nutrition on growth, yield, nutrient uptake and quality of safflower (Carthamus tinctorius L.). Karnataka J. Agric. Sci. 21: q 382-385.

Shabbir, A.N., Ashraf, M.Y., Waraich, E.A., Ahamad, R. and Shahbaz, M. (2015). Combined effects of drought stress and npk foliar spray on growth, physiological processes and nutrient uptake in wheat. Pak. J. Bot. 47: 1207-1216.

Sharma, S.K., Chaudhary, K. and Kumar, M. (2019). AICRPDANICRA Centre Annual Report, CCS Haryana Agril. University Hisar, Haryana, pp 52.

Singh, S.K., Sharma, M., Reddy, K.R. and Venkatesh, T. (2018). Integrated application of boron and sulphur to improve quality and economic yield in potato. J. Environ. Bio. 39: 204-2010.

Verma, G.P. and Singh, Y.P. (2017). Rainfed farming development in central India. Scientific publishers, India. pp. 224.

West, T.O and Marland, G. (2002). A synthesis of carbon sequestration, carbon emissions and net carbon flux in agriculture: comparing tillage practices in the United States. Agric Ecosystems Environ. 91: 217-232.

Zambre, P.B., Kolekar, P.T. and Ughade, S.R. (2017). Effect of foliar sprays of water soluble fertilizer, growth regulator and micronutrients on yield and quality of soybean. Int. J. Agr Sci. 13: 159-160. 